\title{
Media and the sacralization of history
}

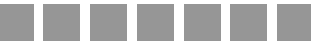 \\ Krzysztof Wasilewski
}

Regional and municipal public library In gorzóW WIElKopolski, poland

DOI: 10.19195/1899-5101.9.1(16).8

\begin{abstract}
This article presents an analysis of the process of sacralization of history in the media discourse. Certain events and figures from the past are incorporated into the sphere of sacrum which excludes any discussion and maintains the domination of one narration of history. The process of sacralization may take places directly or indirectly. The first relies on direct inclusion to the discourse of certain words, which are associated with religion. The indirect sacralization takes place when episodes from the past are changed into universal stories of fight between the good and the evil. The analysis is performed on printed media discourses concerning three events from Poland's contemporary history: the 1920 Warsaw Battle of Warsaw, the 1944 Warsaw Uprising and the postwar armed underground.
\end{abstract}

KEYWORDS: history, collective memory, discourse, religion, sacralization, media.

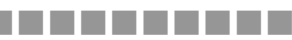

\section{INTRODUCTION}

This article aims at analyzing the process of sacralization of history in the media discourse. By this I understand the incorporation of certain past events into the sphere of sacrum (Stevenson, 2010). In this sense sacralization can be regarded as the final phase of idealization or mythologization of history (Nowak, 2000, pp. 317-343). While the latter two latter do not exclude questioning or even rejection, sacralization is absolute. As our perception of the past also influences our contemporary political choices, there is no surprise that the media grow more and more interested in reporting on history (Ponczek, 2013, p. 8). The press, radio, television and - most recently - internet - they all include historical references in their everyday content. Let it be an account of an official anniversary celebration or a biographical sketch of an important figure from the past. Whatever it is, the way it appears in the media has a considerable impact on what and how people think about it. Naturally, some episodes and figures from the past garner more attention from the media than others. Moreover, by being continuously present in the mainstream media, they gain a reputation seen as essential to maintain the identity of the entire society. Therefore, my hypothesis is that media depict certain 
aspects from history as sacred, whose value for the society is beyond any discussion. In other words, if something is sacred, it should not be discussed but accepted in general (Christou, 2007, pp. 709-722). Just like Catholics should faithfully follow the pope's teachings, so every member of the society should follow the mainstream media interpretation of history. The reference to religion is not incidental. Turning an event from the past into a religious experience prevents it from being disputed by potential opponents. However, if any critics do appear, they face public anathema similar to the excommunication imposed on those who have broken the official rules of the Church. It can be also noted that history and religion are:

[...] domains of categorically differentiated cultural practice that simultaneously unite and divide. (Brubaker, 2015, p. 86)

\section{HYPOTHESIS}

The hypothesis is that the media presentation of certain events from the past leads to their sacralization in the society. This hypothesis derives from both quantitative and qualitative analysis of media discourses. I assume that for what I call the media sacralization of history to occur, certain conditions must be met. When it comes to the quantitative aspect of discourses, the greatest chance of being sacralized (or mythologized) hold those subjects that garner the most attention from the media. Still, what is even more important, is how they are presented by the radio, press, television or internet, since not every subject that the media find salient is sacralized. For this process to occur, a given discourse must contain specific semantic characteristics as well as references to social, political, religious and cultural aspects of reality in which it was created.

Therefore in this article I am trying to answer the following questions: What was the number of printed media texts on each of the three episodes from Polish history? What language was used by those media to describe them? What were the social, political and other aspects of the discourses on those events?

To answer these questions and test the main hypothesis, I have conducted an analysis of printed media discourses on three episodes from the contemporary history of Poland. The first is the "Miracle at the Vistula River" or the battle of Warsaw, when Polish forces defeated the Red Army in 1920. The theme of the second discourse is the Warsaw Uprising of 1944 waged for the liberation of the Polish capital from the Nazi occupation. The last episode refers to the "cursed soldiers", as is called the Polish armed underground fighting against the communist regime in the first years after 1945 are called. As the majority of the Polish society shares the Catholic faith and its set of values, my understanding of sacralization is based first and foremost on the Catholic doctrine. However, the results of this research may be easily modified for other religious systems. 


\section{METHODOLOGY}

The first step to in conducting a proper discourse analysis is the right selection of material (Lisowska-Magdziarz, 2006, pp. 43-45). For the basic source of texts I used the FIDKAR online database, which is run by the Polish National Library and contains articles from leading Polish newspapers and periodicals from 1996. The FIDKAR not only allowed me to find the majority of the published texts on the three subjects from the period 1996-2015, but also has proved that the highest number of articles appear during anniversaries of a given event. Moreover, I used this tool to research how salient for the Polish printed media are the three selected subjects, assuming that the higher number of texts, the more salient the issue. As for August 31, 2015, the FIDKAR produced 1544 articles on the 1944 Warsaw Uprising (the entry: uprising 1944), 1405 on the so-called cursed soldier (the entry: political and military underground after 1944) and 654 on the 1920 Battle of Warsaw (the entry: war 1919-1920). Such high numbers indicate the importance of all the three topics in the Polish printed media discourse. It is also worth remembering that the FIDKAR gathers texts from 1995 till now. The articles from the earlier period (1990-1995) needed to be found through traditional queries of printed bibliographies and online archives of newspapers and other periodicals. As a combined corpora of so many texts (over 3600) would be too great for proper analysis, I have decided to select from it a smaller sample. Therefore, I constructed the corpora baseding on the following periods: for the Miracle at the Vistula River it was the year 1990 (70th anniversary of the event) and 2015 (95th anniversary); for the 1944 Warsaw Uprising it was the year 1994 (50th anniversary) and 2014 (70th anniversary). Finally, for the so-called cursed soldiers I analyzed those texts that appeared in the first week of March of every year, beginning from 2011 (when on March 1, the National Day of Remembrance of the Cursed Soldiers was first introduced). Such periodization allowed me to observe changes or repetitions in the discourses from different years. I decided to analyze only those texts that appeared in the following mainstream dailies and weeklies: Gazeta Wyborcza, Rzeczpospolita, Polity$k a$ and Wprost. When necessary, I completed the corpora with texts from other titles, as indicated in the bibliography.

The main method that I use here is the critical discourse analysis (CDA). Baseding on the definition provided by Foucault, I give discourse a broader understanding, i.e. more than ways of thinking and producing meaning (Weedon, 1987, p. 108). Therefore, CDA aims at identifying the knowledges contained in discourses and how these knowledges are firmly connected to power relations in power/ knowledge relations (Jäger \& Maier, 2009, pp. 34-35).

A number of researchers, representing various disciplines, have formulated their positive opinions on $\mathrm{CDA}$, underlying its usefulness in finding the real meaning of all the forms of communication. Without discarding the quantitative feature of media analysis (as proved in the paragraph above), CDA allows one to focus on 
the very core of each text since it takes into consideration not only semantics, but all the relationships between language, society, power, ideology, politics and culture. For the purposes of this article, which includes both historical and contemporary aspects of media discourses, I drew theoretical and practical principles from the discourse-historical approach (DHA), which has been - with a considerable success - developed mainly by Wodak (Reisigl \& Wodak, 2009, pp. 87-121).

\section{MEDIA, RELIGION AND HISTORY}

The mass media play an important role in the process of shaping the collective memory. As one scholar noted:

[...] a tremendous amount of our understanding of the world is influenced by what we read, watch or hear in the media. This is no less true concerning our understanding of the past. (McCormack, 2010, p. 133)

The everyday presence of the media in our lives has led to a situation where the press, radio, television or internet have taken the responsibility previously reserved for such traditional institutions as the family, school or the Church. In his study on collective memory, Nora argued that:

[...] we have seen the tremendous dilation of our very mode of historical perception, which, with the help of the media, has substituted for a memory entwined in the intimacy of a collective heritage the ephemeral film of current events. (Nora, 1989, pp. 7-8)

Perhaps the most telling example of the power of the media to create collective memory is the US media depiction of the Holocaust. Although a number of historians and witnesses had spoken on the Jewish genocide as soon as the end of World War II, it was not until the 1970s that it became a center point of the American collective memory. Thus, people with no connection to the victims (or perpetrators) of the Holocaust have accepted it as their shared experience from the past (Levy \& Sznaider, 2002, p. 324). The media started the process of Americanization of the Holocaust, that is they have transformed a Jewish story to an American one (Rotem, 2013, p. 10). This paradox was explained by Lipsitz:

Time, history, and memory become qualitatively different concepts in a world where electronic mass communication is possible. Instead of relating to the past through a shared sense of place or ancestry, consumers of electronic mass media can experience a common heritage with people they have never seen; they can acquire memories of a past to which they have no geographical or biological connection. (Lipsitz, 2012, p. 4)

Having said that, it must also be remembered that the media do not yield unlimited power over how people perceive history. Rather, the media indicate which events from the past are worth remembering and which should be forgotten (McQuail, 2007, p. 452). Whether they can also influence people what to think about 
those events depends mainly on several other factors, such as official politics of memory or the society's culture and tradition. When it comes to sacralization of the certain events, Sumiala-Seppänen and Stocchetti underline that:

[...] the process of sacralization is actually performed as a communicative behavior involving the media and the crowd as the main actors and a number of symbols whose meaning is actually shared by the community. While the role of the media is certainly influential, the role of culture specific values and representation system should not be underestimated. (Seppänen \& Stocchetti, 2005, p. 229)

Again, the Holocaust and its media depiction serve as a good example. Most scholars emphasize the consistent work of both the media and official institutions that managed to create the contemporary sacred picture of the Holocaust in Israel and elsewhere. As Levy \& Sznaider point out:

[...] both the original suppression and the current sacred remembrance were equally the expression of Israel's institution, its self-understanding, and its place in the world. (2002, p. 320)

It would not be an exaggeration to write that all states (both democratic and authoritarian) use the media to sacralize fragments of their past.

The Holocaust is also an example of how collective memory is influenced by religion. Just like the media, religion creates sacred texts, which Assmann defines as linguistic utterances that are linked with the idea of the presence of something sacred (Assmann, 2006, p. 109). Such texts serve people as guidance during various hardships - past and present. When it comes to collective memory, religion gives not only some relief but first and foremost it gives an explanation of the past. The same can be said of the contemporary media that - as Nora put it - have replaced religion in explaining history. By sacralizing chosen aspects of the past, the media use the same rhetorical (among others) means as religious sacred texts.

The media construct the desired picture of the past through various lexical and rhetorical devices. Historical discourse, being part of political discourse, can be defined as

[...] the use of language to do the business of politics and [it] includes persuasive rhetoric, the use of implied meanings, the use of euphemisms, the exclusion of references to undesirable reality, the use of language to arouse political emotions and the like. (Chilton, 2008, p. 226)

A number of scholars and writers have commented upon that on the flexibility of the language of political discourse, to mention only Orwell (2013) or Głowiński (2009). Most of researchers agree that political discourse can be manipulated at three stages. Creators of such a discourse first introduce "essentially contested concepts" which:

[...] can endlessly be both supported and contested by rational arguments of different kinds, all of which are valid. (Gallie, 1956, p. 169) 
At the second level, those concepts are described by the media that - depending on their goals - may support them, criticize them or even mute them. This process is called deep and shallow processing (Chilton, 2008, p. 227).

Finally, presupposition is the last phase of discourse manipulation, in which media spread knowledge among the public (Van Dijk, 2008). Through the aforementioned devices, the media create the dominating picture of the past. This process is called "representation" since it decides how:

[...] language is employed in different ways to represent what we can know, believe and perhaps think. (Wilson, 2001, p. 401)

Through language religion is experienced and understood. As Ricoeur proved:

[...] whatever ultimately may be the nature of the so-called religious experience, it comes to language, it is articulated in a language, and the most appropriate place to interpret it on its own terms is to inquire into its linguistic expression. (Ricoeur, 1995, p. 35)

Thus, the sacralization of history in the media discourse takes place at all three aforementioned stages. In the beginning, the creators of the media discourse (politicians, journalists, professional historians etc.) introduce essentially contested concepts that take the form of words and phrases usually associated with religion. To name only a few: sacrifice, morality, evil forces, miracle, fate. Without a doubt they all belong to religious vocabulary, yet their definitions are broad enough to serve various agendas. Let's take the word "sacrifice" for example. It may have positive as well as negative connotations; it can mean making an offering of oneself for a greater purpose, but it can also mean killing someone else. The Catholic idea of sacrifice differs from the one held by Muslims. Not only religion, however, impacts the way people perceive sacrifice (and other similar phrases). Poles, whose history abounds with tragic events, may find sacrifice as the only right solution in certain circumstances. This notion, on the other hand, seems incomprehensible for nations that used to conquer rather than be conquered.

The clarification of the key words comes during deep and shallow processing. It is when the media clarify the definition of such words, making other denotations irrelevant. Thus, the word "sacrifice" from the example above is here stripped of all its meanings that do not meet the purpose of the discourse. Other definitions are absent in the media, which in consequence ends any discussion before it even starts. Through the media such created presupposition reaches the public. To quote Ricoeur once again:

This kind of discourse does not merely claim to be meaningful, but also to be true. (Ricoeur, 1995, p. 35)

At this stage the process of discourse sacralization is completed. Sacralization of history leads to the exclusion of all alternative narrations. In this sense, sacral- 
ization, as an absolute notion, rejects basic principles of professional history. As some French intellectuals rightly pointed it out:

History is not religion, this is why a scientist must not accept dogmas and injunctions. History is not morality, this is why a historian does not glorify or issue verdicts. His job is to explain. History is not memory or a subject of law. (Eisler, 2010, p. 409)

These rules are not applied to the media, however. Thus, such a discourse serves primarily as a tool through which the majority establishes the dominant picture of the past and excludes the minority (Riggins, 1997, pp. 4-6).

The process of exclusion regarding history can be observed in most societies. Excluded are not just national or ethnic minorities and their perceptions of the past. Other groups, such as political or religious minorities are excluded as well. It is enough to say that until the late 1960s the memory of the Holocaust was marginalized in the public debate in Germany (Wolff-Powęska, 2011, pp. 118-134) whereas in France very few historians and journalists were brave enough to openly discuss the country's collaboration with the Nazis. As some scholars note, the contemporary Israeli historiography still mutes the Palestinian perspective, just like former colonial powers still marginalize narrations of the colonized nations. Sacralization of history in the media takes the process of exclusion to yet another level. Not only are certain events and people presented by the media as sacred, but also other elements of the past that do not meet the majority's acceptance become excluded or - to use a religious metaphor - cursed from the public debate. As one scholar noted:

[...] what memories we learn to judge as innocuous, inappropriate or openly against the interests of the nation, institutions, groups or communities has very little to do with chance, and much to do with political and social construction. (Riaño-Alcalá et al., 2013, p. 31)

\section{THE MIRACLE AT THE VISTULA RIVER}

When Poland regained independence in November 1918, the future shape of its frontiers remained unknown. Much like the rest of Central Europe, also here every now and again erupted conflicts between neighbors over contested territories. Only in the years 1918-1921 Poland was drawn into border disputes with Germany, Czechoslovakia, Lithuania and Soviet Russia. Among them the latter poised the greatest danger, not so much because of its size, as because of its communist ideology that was gaining on popularity throughout the entire continent. After major successes of the Polish Army in 1919, it was Russia that seized the initiative in the following year. The Red Army not only managed to expel Poles and their Ukrainian allies from its homeland, but also made some serious gains into the Polish Republic, reaching the outskirts of Warsaw in August 1920. With the Polish capital in their hands, the Russians would have had the road to the West open. Yet, by un- 
expected military maneuvers, Poles managed to withstand the attack, save their capital and push the Red Army back (Pruszyński, 1999). The Ffollowing months brought no breakthroughs for either side, which resulted in the signing of a peace treaty in March 1921. In the contemporary Polish historiography the battle of Warsaw holds one of the major places, being perceived by both historians and laymen as crucial in maintaining the country's newly restored independence and saving Europe from communism.

The phrase "miracle at the Vistula River" was coined within the first weeks after the battle. The politician and historian Stroński repeated on several occasions that:

[...] we were praying for a miracle and that miracle came true. (Krasuski, 2000, p. 64)

His original intention was to undermine the military and political command of his political opponent Józef Piłsudski. Within the years, however, the miracle at the Vistula River gained a solid place in professional history and journalism (Wójcik-Łagan, 2013, pp. 545-564). During the communist regime in Poland (1945-1989), the phrase, as well as the official commemoration of the battle, was absent from public life (Ćwięk, 2010, p. 174). It did exist in exile, however, mainly in Great Britain and the United States, where a considerable number of the postwar Polish intelligentsia lived and worked. Through various illegal printed publications and radio broadcasts (Radio Free Europe Polish Service) the memory of the battle in its sacred version had survived among Poles. Just how strong was its presence was proves the content of the samizdat press from the 1980s, where every anniversary of the 1920 was celebrated with a special care (Mikołajczyk, 1998). At that time sacralization of the event served as a tool in the propaganda war against the communist regime. When the communist regime in Poland collapsed in the second half of 1989, the hitherto illegal discourse on the battle of Warsaw became official. No surprise that both national and local media paid much attention to the 70th anniversary of the event in 1990. The then most acclaimed daily Gazeta Wyborcza quoted Pope John Paul II, who thanked for that great mercy of history, for that great gift of God's providence. The same paper also cherished the fact that after the years of the communist indoctrination in history textbooks, pupils and students would finally learn who was the real author of the "miracle at the Vistula River". Just like official celebrations were dominated by their religious aspect, so was the media discourse on the battle founded on religious language. Journalists wrote about a military and spiritual victory, a battle that proved the strength of the Polish soul, or about a fight that saved Europe from the evil forces of communism. Even those who distanced themselves from the idea of a miracle, could not eradicate their language from religious elements and as such took part in sacralization of the event.

Within the years, the discourse on the miracle at the Vistula River had secured its domination in the public debate. Naturally it now enjoys the strongest position 
in conservative media - both secular and owned by the Catholic Church. Though being a considerable part of the Polish media system, their range is limited. In other words, had it not been not for the mainstream media, the sacralization of the 1920 Warsaw battle would have never reached such a level. It must be underlined that in this example the process of sacralization takes place directly. An analysis of the major Polish press titles (as well as radio and television programs) since 1989 shows how that phrase has anchored in the public debate. Every anniversary of the battle is commemorated by the state-owned and still very popular TVP television, with a special program entitled The Miracle at the Vistula River. The Polish Radio usually repeats that pattern.

Even liberal press titles do not hesitate to include the phrase into their commentary. Let us serve for the example the left-wing weekly Polityka. In one of his articles, the weekly's acclaimed publicist Władyka wrote:

In August 1920, at the doorstep of the Second Polish Republic, the first miracle happened. Poland halted the Bolshevik offensive and saved Europe from the revolution. (2008, p. 20)

According to the author, the second miracle in Polish history took place on June 4, 1989, that is when the first after II World War semi-democratic elections were held since the end of the Second World War, beginning the collapse of the communist regime. By direct sacralization of these two events, the journalist achieved two goals. First, he placed them on the top of the most important events in the country's past. Second, he excluded from the discourse those who might not agree with such a selection of top events from the country's contemporary history. In other words, the journalist not only sacralized two episodes from the Polish past, but also desacralized alternative narrations.

Narrations that reject any connotations to religion have been eradicated from the mainstream media and stigmatized as blasphemous. Usually such journalists were accused of repeating the notorious communist propaganda about the battle or not understanding the national spirit. Thus, it comes as little surprise that their opinions appeared only in partisan media. What is interesting is that similar sentiments can be found in both left-wing (so-called post-communist) and some conservative media.

\section{WARSAW UPRISING}

How important is the 1944 Warsaw Uprising for the Polish identity is proven by every anniversary of that event. Since 1989 it has evolved from a local history into a national holiday, commemorated both in the capital and province.

The Warsaw Uprising broke out on August 1, 1944. The underground Home Army decided it was the right time to free Warsaw from the Nazi occupation as the Soviet Army had been spotted at the outskirts of the Polish capital. As it turned 
out, however, the uprising had been poorly prepared. The majority of the Polish forces comprised of the youths - poorly trained and even more poorly equipped. A machine gun or a pistol were scarce. Moreover, the German strength had been underestimated, as it was believed that most Nazis had already left the city. In fact, it was on the contrary was true. But perhaps the gravest mistake made by the Home Army was its position on the Soviets (Ciechanowski, 1971, p. 121). Polish commanders counted on the support from the Red Army even though earlier experience would order precaution. Still, the Soviets had not been informed about the planned uprising, which limited their capabilities to reinforce the Poles - had they wanted to do so. Finally, the Home Army leadership admitted that militarily, the uprising was aimed at the Germans but politically it was directed against the Soviets. Such a strategy guaranteed not victory, but failure. After over two months of heavy fighting, over 200 thousand people (mostly civilians) had been killed, with Warsaw being completely destroyed. It was not until January 1945 that the Polish capital was liberated by the Red Army and pro-communist Polish Army.

The communist propaganda in Poland - perhaps with the exception of the years 1948-1956 - presented the Warsaw Uprising as an unforgivable mistake of the Home Army leadership and - in contrast to this narration - as a heroic fight of young soldiers against the Nazis. In various official declarations, politicians and journalists spoke of the uprising as yet another example of wishful-thinking of political bankrupts that had cost hundreds of thousands of lives of ordinary people. Also a significant part of the immigration intelligentsia perceived the failure of the Warsaw Uprising as the main factor that had enabled the communists to gain power in Poland. Some of Polish writers in Great Britain or the United States were even more brutal in their critique of the uprising than the communist media at home (Mackiewicz, 2012; Pobóg-Malinowski, 1990).

The narration about the uprising changed dramatically after 1989 . Within several years, the 1944 Warsaw Uprising had become the most important episode in Poland's contemporary history, an. The episode that decided upon the country's future and the spirit of the entire nation. Politicians and journalists alike perceived it as a symbol of Poland's unbreakable spirit, the beginning of anti-communist opposition and finally, as a moral victory. Any critique was barred from the mainstream media. As the military failure was blunt, its apologists have decided to sacralize the uprising. Contrary to the original goals of the Home Army leadership, contemporary historians and publicists maintain that the real purpose of the uprising was not the actual liberation of the Polish capital but rather the spiritual liberation of the entire Polish nation. Among the arguments put forward in the media debate three have dominated: First, Stalin would have made Poland part of the Soviet Union. Secondly, there was the moral imperative to wage war against the Nazis, even if there were no chances of winning that fight. Thirdly, the uprising was a sacrifice necessary to save the nation's soul. 
As it can be observed, only the first argument was of a purely historical nature. However, as most professional historians agree, there is no proof that the uprising influenced Stalin's decision about the future of Poland (Ciechanowski, 1971, p. 230). In fact, most sources confirm that the Soviet leader had no plans to make Poland one of the provinces of the USSR. Still, such argumentation excuses the failure of the uprising, since after 1945 Poland remained a country on its own. The second and third arguments have no historical basis but are founded on religious concepts: moral imperative and sacrifice. According to the Catholic doctrine, moral imperative can be understood as:

[...] some sort of necessity, imposed on the will, of doing what is good and avoiding what is evil. (Habermann, 1913, p. 189)

In this sense, the Home Army leaders felt morally obliged to start the uprising by which they hoped to demonstrate their objection to the situation in which Poland had found itself in the second half of 1944. Such a demonstration - as it has already been mentioned - - was aimed not only at the Nazis but also at the Soviets, as the results of the Tehran Conference had long been known by then. The concept of moral imperative makes any questions about the legitimacy of waging an uprising in such difficult conditions insignificant. Whatever human losses the uprising brought, they could have not excused inaction. Moreover, moral imperative marks any doubts as blasphemous as they undermine the entire foundation of the religion.

The introduction of sacrifice to the media discourse on the uprising has even strengthened its position as the most sacred element of the Polish contemporary history. The idea of sacrifice has always played an important role in the Polish historiography. In order to explain the nation's troublesome past, abounding with lost wars and periods of subjection, many historians and publicists have found a satisfying explanation in religion. It was religion, namely Catholicism, that offered answers to the question about Poland's place and role in the world history. Due to religion, such events as the three partitions of Poland (1772-1918), when the country remained erased from the map of Europe, could finally be explained and understood. According to the still common understanding, Poland sacrificed itself in order to protect freedom against the despotic regimes of Prussia, Russia and Austria-Hungary. In other words, Poland had to die, to let freedom live. The idea of sacrifice explains the country's history, gives the society a sense of pride and perhaps most importantly - mutes all the critical narrations. Just as with moral imperative, also sacrifice releases historians from delving in a search for the reasons of the fall of Poland in the 18th century and other national dramas.

The same reasons explain why the media reach for the idea of sacrifice in regard to the 1944 Warsaw Uprising. Let one editorial from the the Rzeczpospolita daily serve as an example. The newspaper's publicist called the uprising an act of heroism, idealism and visionary (Sokołowski, 2014). In his opinion no one had the right to 
judge the uprising as unrealistic and bound to failure, since different goals had stood behind the decision made by the Home Army. The author did not refer to the ideas of sacrifice or moral imperative openly, but his intentions could be easily deducted. To quote him:

Realists are often right, but it is not them who change the world for the better. This is done by dreamers, who may be often wrong, but we owe them that now we travel by airplanes or live in a democratic world. (Sokołowski, 2014)

Contrary to the Miracle at the Vistula River, where sacralization rests on direct linguistic associations (the open usage of the word "miracle"), the media discourse on the Warsaw Uprising seems to be more veiled. As in the aforementioned example from the Rzeczpospolita newspaper, such words as sacrifice, moral imperative or martyrs do not even have to be present. What is more important is what the author implies indirectly, for example by comparing the insurgents to dreamers who invented the plane or by turning them from local fighters into universal heroes who gave their lives for global freedom. This process is additionally strengthened by the media broadcast of the Warsaw Uprising anniversaries. They always include religious celebrations which - together with the language used in the discourse - create a picture of an extraordinary event from the past where history and religion intertwine.

\section{THE CURSED SOLDIERS}

The narration on the "cursed soldiers" is the latest element in the official Polish politics of memory. Even though some journalists and politicians had talked about the post-war armed underground before, it was not until 2011 that the official national commemoration day (1 March) was approved by the parliament.

The new interim Polish government was internationally recognized in June and July 1945. It meant that not only the Soviet Union but also western powers, most notably the United States and Great Britain, had acknowledged the domination of the communists in Poland as a fait accompli. It is impossible to estimate what percentage of the nation sympathized with the new reality. It would be acceptable, however, to say that the prevailing mood among the majority of Poles was the need to rebuild the country, whatever party was in power. Still, there was strong opposition to the communist rule (Sowa, 2011, p. 37). Its most radical form was the armed underground, comprised of up to 180000 soldiers, usually former members of the Home Army and other underground groups. Still, fewer than half of that number were active members. Those who were, operated in the forests, usually attacking small militia stations and anyone who in their opinion collaborated with the communists. According to the underground, among traitors were not only members of the communist party (PPR), but also militiamen, soldiers and farmers who received land from the government. Both sides did not refrain from brutality, whichat raised 
the number of innocent victims even higher. Although the majority of underground groups had been destroyed by the end of 1948, the remnants carried on fighting as long as 1956 (Wnuk et al., 2007).

During the Stalinist period in Poland (1948-1956) and shortly after it, the communist propaganda framed the armed underground as bands of common robbers, anti-Semites and criminals who had fought against the legitimate government and the nation. However, starting from the late 1970s, most historians began to call the years 1945-1948 a civil war period, during which both sides had their rights and wrongs (Werblan, 2009). It was not until the onset of the 21st century that the cursed soldiers transpired to the public media, mainly due to conservative journalists and politicians. With the formation of the Institute of National Remembrance (IPN) in 1999, the official narration on the first years after the war was reduced to a simple fight between the good (the underground) and the evil (the communist regime). On one side there were faultless cursed soldiers who gave up their lives for freedom and democracy; on the other there were the Soviet puppets who aimed at enslaving the Polish nation.

Similarly to the first two examples, the media quickly accepted such a division. After all, it met all the requirements of an interesting media material: strong characters, a clear division between the good and the bad, and a tragic ending. Cursed soldiers were patriots of flesh and blood with strong principles, ready to die for their cause. In this sense they can be perceived as the successors of the Warsaw insurgents and their spiritual heirs. Due to this fact, the question about the reasonability of their fight becomes irrelevant as they followed a moral imperative. In other words, they simply did what was right at that time, regardless the consequences. The media discourse has made no space for any discussion of their motives or behavior, which - according to some historical sources - did not always meet gallant standards. The adjective "cursed" has added to them a tint of supernatural abilities. Moreover, the pseudonyms they used, such as Ogien [Fire], Eupaszka [Raider] or Ryś [Lynx], have moved the imagination of the youth, who want someone they could identify with. It is not surprising that apart from history books and press articles, there have appeared comics were published on the cursed soldiers. Members of the post-war underground have become modern-day national heroes whose pictures and names are spread during sports events, music concerts or patriotic meetings. On the other side there are the communists, usually presented as a homogeneous and evil group. Hardly ever the media hardly ever bring closer the disputes that then took place then within the communist elite.

The sacralization of the media discourse on the post-war armed underground proceeds along two lines. The first - and direct line - copies the pattern introduced in the discussion on the Miracle at the Vistula River. As the adjective cursed belongs to the sphere of religion, it releases the discourse from any restrictions that professional history might impose on it. Due to this fact, the media are free to present the years 1945-1948 as a battle between the cursed (the underground) and 
the damned (the communists). It is worth noticing the difference between these two adjectives: cursed and damned. Although both words are often used as synonyms, in this sense they represent two opposite formations. Members of the underground were cursed because the communists not only tried to present them in a negative light but also wanted to erase them from history. Thus, the cursed soldiers had to fight with the actual enemy, as well as for the right place in history. Similarly, damnation came for the communists not just because they acted against the nation's moral imperative but also because they tried to revise history.

The second - indirect line - resembles the narration on the Warsaw Uprising. Here, narration - even if lacking direct references to religion - is built on religious foundations. It means that the authors of the discourse use the same themes that their receivers are familiar with. The cursed soldiers are thus presented as the only righteous men besieged by evil forces, as sacrificers who gave up their lives for freedom of the others or defenders of the faith (since the communists proclaimed atheism). These are themes well known from the Bible stories.

The sacralization of the discourse on the post-war underground enables the media to use this topic far from its historical context. As some journalists maintain, the legacy of the cursed soldiers is still alive and continued by certain political groups. Such thinking leaves little or no doubt at all as to where other parties belong. During the 2015 presidential campaign in Poland this patriotic issue was greatly used by the conservative media. Journalists reminded that the father of the incumbent president had not joined the cursed soldiers but had chosen to rebuild the country peacefully. On the other hand, his main contender was to represent the righteous set of values as his family members had taken part in various national uprisings. Much like with the discourse on the 1944 Warsaw Uprising presents its goals as still valid, so is the fight of the cursed soldiers unfinished.

\section{CONCLUSION}

Having replaced religion, the media now play the leading role in sacralizing the past. This process takes places at several stages. At first, events or persons from the past must gain greater attention from the media than others. Only then it is it possible for them to secure their sacred position in the society. The sacralization of the media discourse on history takes places directly and indirectly. The first relies on the direct usage of certain words that connote with religion. In the aforementioned examples the three most important were: miracle, sacrifice and curse. They may be called frames through which the media present those events from Poland's recent past: the 1920 battle of Warsaw, the 1944 Warsaw Uprising and the post-war underground. The indirect sacralization of the discourse takes place through narration that uses religious themes that are well-known in the predominantly Catholic nation. Journalists and other authors of the discourse turn episodes from the past into universal stories of the fight between the good and evil where the right answer to 
the calling of moral imperative becomes the main and only determinant of a success or failure.

Such a depiction of certain historical events by media leads to their sacralization in the society. The episodes that were analyzed in this article are only three - perhaps the most evident - examples from a long list. They are, however, the most evident, ones and universal enough to produce general conclusions. Thus it can be assumed that the analysis conducted in this article supports its hypothesis. They meet all the requirements of the sacralization process: historically importance, media attention, and direct and indirect links to the predominant religion. There is common agreement, also shared by professional historians, that these episodes played a crucial role in Poland's past. This notion is supported by the attention they receive from the mainstream media, which strengthen their message by depicting them as religious experiences. In addition, all the criticism of the dominating narrative falls into the categories of blasphemy and treason. This not only excludes and mutes any counter narrative but first and foremost rejects it from the permissible discourse.

Sacralization of history is by no means a Polish specialty. Every nation builds its own mythology and the role of the media in this process can hardly be overestimated. Perhaps the most telling examples are contemporary Russia and Ukraine. In both these countries any critique of the official narration on the Great Patriotic War (Russia) and the Ukrainian Insurgent Army is penalized. It can be stated that the greater need for national unity, the stronger sacralization of the nation's past. In other countries the sacralization of the media discourse on history takes less drastic forms, but it still excludes those who present different opinions. Therefore the sacralization of history by the media not only sets the dominating picture of the past, but also strengthens the rule of the majority.

\section{REFERENCES}

Assmann, J. (2006). Religion and Cultural Memory. Stanford, CA: Stanford University Press.

Brubaker, R. (2015). Grounds for Difference. Cambridge, MA: Harvard University Press.

Chilton, P. (2008). Political terminology. In: Knapp, K., Antos, G. (eds.). Handbook of Communication in the Public Sphere. Berlin: Walter de Gruyter GmbH\&Co., pp. 226-242.

Christou, M. (2007). The language of patriotism. Sacred history and dangerous memories. British Journal of Sociology of Education, 28 (6), pp. 709-722.

Ciechanowski, J.M. (1971). Powstanie warszawskie [The Warsaw Uprising]. Warsaw: Państwowy Instytut Wydawniczy.

Ćwięk, H. (2010). O obronie Warszawy w 1920 roku. Fakty i mity [On the defence of Warsaw in 1920]. In Ponczek, E., Sepkowski, A. (eds.). Mity historyczno-polityczne. Wyobrażenia zbiorowe. Polityka historyczna. Studia i materiały [Historical and Political Myths. Collective Ideas. Politics of Memory. Materials and Studies]. Volume 1. Toruń: Wydawnictwo Adam Marszałek.

Eisler, J. (2010). Narracje o PRL. Jak się opowiada o historii najnowszej? [Narrations on the Polish People's Republic. How is contemporary history told?] In: Bolecki, W., Madajski, J. (eds.). Zapisywanie historii. Literaturoznawstwo i historiografia [Writing History. Literary Studies and Historiography]. Warsaw: Wydawnictwo Instytutu Badań Literackich. 
Gallie, W.B. (1956). Essentially contested concepts. Proceedings of the Aristotelian Society, 56 (19551956), pp. 167-198.

Głowiński, M. (2009). Nowomowa i ciagi dalsze [Newspeak and Further Developments]. Cracow: TAiWPN Universitas.

Habermann, Ch.G., Pace, E.A, Pallen, C.B, Shahan, T.J., Wynne, J.J. (1911). The Catholic Encyclopedia. Volume 11. Albany, NY: The Encyclopedia Press, Inc.

Jäger, S., Maier, F. (2009). Theoretical and methodological aspects of Foucauldian critical discourse analysis and dispositive analysis. In: Wodak, R., Meyer, M. (eds.). Methods of Critical Discourse Analysis. Thousand Oaks, CA: SAGE, pp. 34-61.

Krasuski, J. (2000). Tragiczna niepodległość. Polityka zagraniczna Polski w latach 1919-1945 [Tragic Independence. Poland's Foreign Policy in 1919-1945]. Poznań: Wydawnictwo Poznańskie.

Levy, D., Sznaider, N. (2002). Cosmopolitanization of Holocaust memory. In: Gerson, J.M., Wolf, D.L. (eds.). Memories and Identities in Jewish Diasporas. Durham, NC: Duke University Press, pp. 313-330.

Lipsitz, G. (2012). The case for studying popular culture. In: Franz, K., Smulyan, S. (eds.). Major Problems in American Popular Culture. Documents and Essays. Boston, MA: Wadsworth.

Lisowska-Magdziarz, M. (2006). Analiza tekstu $w$ dyskursie medialnym [Text Analysis in Media Discourse]. Cracow: Wydawnictwo Uniwersytetu Jagiellońskiego.

Mackiewicz, S. (2012). Lata nadziei. 17 września 1939-5 lipca 1945 [The Years of Hope. September 17, 1939-July 5, 1945]. Cracow: TAiWPN Universitas.

McCormack, J. (2010). Collective Memory. France and the Algerian War (1954-1962). Plymoth: Lexington Books.

McQuail, D. (2007). Teoria komunikowania masowego [The Theory of Mass Communication]. Warsaw: PWN.

Mikołajczyk, M. (1998). Jak się pisało o historii... Problemy polityczne powojennej Polski w publikacjach drugiego obiegu lat siedemdziesiątych i osiemdziesiatych [How It Was Written about History... Political Problems of Post-War Poland in the Samizdat Publishings in the 1970s and 1980s]. Kraków: Księgarnia Akademicka.

Nora, P. (1989). Between history and memory: Les Lieux de Memoire. Representations, 26, pp. 7-22.

Nowak, L. (2000). On the common structure of science and religion. Poznań Studies in the Philosophy of the Sciences and the Humanities, 73, pp. 317-343.

Orwell, G. (2013). Politics and the English Language. London: Penguin Books.

Pobóg-Malinowski, W. (1990). Najnowsza historia polityczna Polski 1864-1945 [Contemporary History of Poland 1864-1945]. Volume 3. Warsaw: Krajowa Agencja Wydawnicza.

Ponczek, E. (2013). Polityka wobec pamięci versus polityka historyczna: aspekty semantyczny, aksjologiczny i merytoryczny w narracji polskiej [Politics and Memory versus Politics of Memory. Semantic, Axiological and Essential Aspects in the Polish Narration]. Przeglad Politologiczny, 2, pp. 7-22.

Pruszyński, M. (1999). Dramat Piłsudskiego. Wojna 1920 [Pilsudski’s Drama. The 1920 War]. Warsaw: Polska Oficyna Wydawnicza BGW.

Reisigl, M., Wodak, R. (2009). The discourse-historical approach (DHA). In: Wodak, R., Meyer, M. (eds.). Methods of Critical Discourse Analysis. Thousand Oaks, CA: SAGE, pp. 87-121.

Riaño-Alcalá, P. et al. (2013). Remembering and Narrating Conflict. Bogota: Imprenta Nacional de Colombia.

Ricoeur, P. (1995). Philosophy and religious language. In: Wallace, M.I. (ed.). Figuring the Sacred: Religion, Narrative and Imagination. Minneapolis, Minn.: Fortress Press.

Riggins, S.H. (1997). The rhetoric of othering. In: Riggins, S.H. (ed.). The Language and Politics of Exclusion. Thousand Oaks, California: SAGE.

Shosh, R. (2013). Constructing Memory: Architectural Narratives of Holocaust Museums. New York: Peter Lang. 
Sokołowski, P. (2014). Romantyzm, heroizm, poświęcenie [Romanticism, heroism, sacrifice]. Rzeczpospolita, August 8, p. A11.

Sowa, A.L. (2011). Historia polityczna Polski 1944-1991 [Political History of Poland 1944-1991]. Warsaw: Wydawnictwo Literackie.

Stevenson, A. (ed.). (2010). Oxford English Dictionary of English. Oxford: Oxford University Press.

Sumiala-Seppänen, J., Stocchetti, M. (2005). Mediated sacralization and the construction of postmodern communion sanctorum. The case of the Swedish Foreign Minister Anna Lindh. $M a-$ terial Religion, 1 (2), pp. 228-249.

Van Dijk, T. (2008). Discourse and Context. A Sociocognitive Approach. Cambridge: Cambridge University Press. Weedon, C. (1987). Feminist Practice and Poststructuralist Theory. Oxford: Basil Blackwell.

Weedon, C. (1987). Feminist Practice and Poststructuralist Theory. Oxford: Basil Blackwell.

Werblan, A. (2009). Stalinizm $w$ Polsce [Stalinism in Poland]. Warsaw: Towarzystwo Wydawnicze i Literackie.

Wilson, J. (2001). Political discourse. In: Schiffrin, D., Tannen, D., Hamilton, H.E. (eds.). The Handbook of Discourse Analysis. Oxford: Blackwell.

Władyka, W. (2008). Cuda nad Wisłą [Miracles at the Vistula river]. Polityka, 45, pp. 20-22.

Wnuk, R., Poleszak, S., Jaczyńska, A., Śladecka, M. (2007). Atlas polskiego podziemia niepodległościowego 1944-1956 [The Atlas of the Polish Independence Underground 1944-1956]. WarsawLublin: Wydawnictwo Instytutu Pamięci Narodowej.

Wójcik-Łagan, H. (2013). Mitologizacja postaci i wydarzeń w świetle podręczników do historii z lat trzydziestych XX wieku [The mythologization of persons and events in the light of history textbooks in the 1930s]. In: Koko, E., Nowak, M., Zaszkilniak, L. (eds.). Historia - Mentalność Tożsamość. Rosja i Europa Zachodnia w polskiej i ukraińskiej historiografii XIX i XX wieku [History - Mentality - Identity. Russia and Western Europe in Polish and Ukrainian Historiography in the 19th and 20th Centuries]. Gdańsk: Wydawnictwo Uniwersytetu Gdańskiego.

Wolff-Powęska, A. (2011). Pamięć - brzemię i uwolnienie [Memory - Burden and Exoneration]. Poznań: Wydawnictwo Zysk i S-ka. 